\title{
THE REVITALIZATION MODEL THROUGH THE IMPLEMENTATION OF ACCOUNTING INFORMATION SYSTEM FOR VILLAGE UNIT COOPERATIVE IN BANYUMAS REGION, INDONESIA
}

\author{
Eko Suyono \\ Faculty of Economics and Business, Jenderal Soedirman University, Indonesia \\ E-mail:ekyo75@yahoo.com \\ Oman Rusmana \\ Faculty of Economics and Business, Jenderal Soedirman University, Indonesia \\ E-mail:omanrms@gmail.com \\ Riswan \\ STIE Muhammadiyah Pekalongan \\ E-mail: riswan5310@yahoo.com
}

Received: November 2018; Accepted: November 2018; Available online: January 2019

\begin{abstract}
One of the obstacles faced by the Village Unit Cooperative (VUC) in dealing with the current competitive business environment is the limited resources both in term of funds and infrastructure. Meanwhile, modern business is supported by the large scale of resources such as modern infrastructure, professional human resources, and extensive networks both at national and international levels. This study tries to evaluate the information system needs by VUC in order to sustain their business both manual and computer-based accounting system. The data was collected through in-depth interview, observation, and focus group discussion during community engagement activity conducted from July to October 2018. By using 6 VUCs in Banyumas as a sample, this study documents the steps in system development by using system development life cycle such as provide general information of the business, a summary of accounting policies, account guidelines and financial statements format, description of account codes, and the forms or the standards of journal entries. Moreover, this study designs a computer-based accounting system by using the Pivot Table on Microsoft Excel. With the good supervision in implementing all steps in system development, it is expected that the VUCs in Banyumas will be more sustainable and professional in managing their business in a very competitive business environment.
\end{abstract}

Keywords: Village Unit Cooperative, Accounting Information System, Computer-based Accounting System, System Development Life Cycle

\begin{abstract}
Abstrak
Salah satu kendala yang dihadapi oleh Koperasi Unit Desa (KUD) dalam menghadapi lingkungan bisnis yang kompetitif saat ini adalah sumber daya yang terbatas baik dalam hal dana dan infrastruktur. Sementara itu, bisnis modern didukung oleh sumber daya skala besar seperti infrastruktur modern, sumber daya manusia profesional, dan jaringan yang luas baik di tingkat nasional maupun internasional. Studi ini mencoba untuk mengevaluasi kebutuhan sistem informasi bagi KUD di Kabupaten Banyumas supaya KUD mampu mempertahankan bisnis mereka melalui implementasi sistem akuntansi manual dan system informasi akuntansi berbasis komputer. Data dikumpulkan melalui wawancara mendalam, observasi, dan diskusi kelompok terarah selama kegiatan pengabdian kepada masyarakat yang dilakukan dari Juli hingga Oktober 2018. Dengan menggunakan 6 KUD di Banyumas sebagai sampel, penelitian ini mendokumentasikan langkah-langkah dalam pengembangan sistem dengan menggunakan pendekatan siklus hidup pengembangan system. Selanjutnya panduan sistem manual
\end{abstract}


memberikan penjelasan seperti gambaran informasi umum bisnis, ringkasan kebijakan akuntansi, pedoman akun dan format laporan keuangan, deskripsi kode akun, dan bentuk atau standar entri jurnal. Selain itu, penelitian ini mendesain sistem akuntansi berbasis komputer dengan menggunakan Tabel Pivot pada Microsoft Excel. Dengan pengawasan yang baik dalam mengimplementasikan semua langkah dalam pengembangan sistem, diharapkan KUD di Kabupaten Banyumas akan lebih profesional dalam mengelola bisnis mereka dalam lingkungan bisnis yang sangat kompetitif dewasa ini.

Kata Kunci: Koperasi Unit Desa, Sistem Informasi Akuntansi, Sistem Akuntansi Berbasis Komputer, Siklus Hidup Pengembangan Sistem

How to Cite: Suyono, E., Rusmana, O., \& Riswan. (2019). The Revitalization Model Through the Implementation of Accounting Information System for Village Unit Cooperative in Banyumas Region, Indonesia. Media Ekonomi dan Manajemen, 34(1), 1-13.

\section{INTRODUCTION}

The existence of cooperatives in Indonesia is inseparable from the concept of populist economy which was encouraged by the founders of Indonesia, namely an economic system that favors the indigenous population, to improve the economic welfare of the society which is characterized by the life of the people's business (Suyono et al., 2016a). Village Unit Cooperative (hereafter, VUC) is a type of business that oversees various business fields, such as agricultural production facilities, trade, agriculture, savings and loans, and so-on. This type of business has been going on for a long time in Indonesia and its benefits have been felt by the wider community and contributed to providing employment and driving the economy of the country (Riswan et al., 2017). In addition, cooperative is a type of business entity mandated by the basis of the constitution for the Indonesian State, i.e., the 1945 Constitution. The existence of VUC in each district has a meaning or role that is very important and beneficial to national economic growth and to increase equitable income for all Indonesian people according to the principle of social justice.

Initially, VUC was formed as a benchmark for Indonesia's economy which is more pivot in the populist economic system. But with the increasingly open era of globalization, many VUCs are unable to compete so that some of those VUCs are no longer exist. It is due to the fact that many VUCs are unable to overcome various business problems in the midst of a competitive business environment so that they cannot develop in an increasingly competitive environment for doing such business. In the meantime, the role of cooperatives will be increasingly severe especially in facing the era of the Millennium Development Goals (MDGs) next coming year of 2020 .

This research conducted through a community service scheme intends to revitalize several VUCs in Banyumas region by designing and implementing an integrated information system so that VUC administrators can supervise all business activities of units owned from the head office. By implementing such an accounting system, the VUC's managers will become more professional in managing the business so that it will be able to survive and compete with other types of businesses. In addition, the application of accounting information system is also expected to be able to overcome various VUC weaknesses in its business management so that it can restore the VUC conditions in Banyumas Region, where almost VUCs are generally in a bad financial performance. In order to achieve this purpose, this study selects several VUCs in Banyumas Region as samples, namely the VUC of Tri Murti in Kembaran District, VUC of Tani Maju located in East Purwokerto district, VUC of Mustika located in Sumbang District, VUC of 
Patikraja located in Patikraja District, VUC of Bahtera located in Baturaden District, and VUC of Endah located in Kedung Banteng District.

\section{LITERATURE REVIEW}

The cooperative is a people's economic movement based on the principle of kinship as stipulated in article 33 paragraph 1 of the 1945 Constitution. As explained by Ropke (1995) cooperatives are business organizations whose owners or members are also the company's main customers. Moreover, the VUC is an all-round cooperative which commonly consists of villagers where its working area usually covers one district (Riswan et al., 2017).

The benefits of VUC according to Instruction of the President of the Republic of Indonesia No. 4 of 1984 Article 1 Paragraph (2) are generally that VUC development is directed so that VUC can become a service center for economic activities in rural areas which are an integral part of national development and fostered and developed in an integrated manner through cross-sectoral programs. The government's assistance is intended to enable the public enjoying the prosperity that can be achieved by the economic development of the people, for example, by providing credit particularly for poor people in the rural areas.

Adequate application of an accounting information system is expected to encourage the professionalism of VUC's managers in managing business transactions, process inputs into useful outputs, which are very important to support managers' decision-making processes (Bodnar and Hopwood, 2010). Furthermore, in the process of system development for VUC, it also compiles various forms, documents, records and financial reports that are in accordance with accounting standards for entities without public accountability so that they become more professional in managing their business (IASB, 2009; IAI, 2011).
Several previous studies in this topic were done by Sam et al. (2012), Relhan (2013), Tijani and Mohammed (2013), Suyono et al. (2016b), Ogundana et al. (2017), Ezeagba (2017), Uddin et al. (2017), etc.

Suyono et al. (2016b) implemented a computer-based accounting information system for managing the microfinance institutions such as Baitul Maal wa Tamwil (BMT) in Banyumas Region, Indonesia. The study designed both models of manual and computerized accounting information systems to increase the professionalism of BMT's managers in managing the business. It is done by starting to organize forms, notes and financial report formats in accordance with accounting standards that apply to microfinance businesses with reference to Financial Accounting Standards for Entities without Public Accountability (SAK-ETAP).

Tijani and Mohammed (2013) evaluated the application of computerbased accounting information systems to SMEs in manufacturing, hotels, restaurants, etc. in Nigeria. The study found that the use of the Computer Based Accounting System (CBAS) had spread to almost all the SMEs that were selected as a sample in the study. Further findings indicate that $18 \%$ of respondents use CBAS to process daily transactions, $36 \%$ weekly, and $46 \%$ monthly. Furthermore, Sam et al. (2012) found that $80 \%$ of SMEs in Melaka, Malaysia had adopted SBAS in the management of their businesses. Relhan (2013) found that 97\% of SMEs who were respondents in India had used CBAS where $62 \%$ of the software category used Turnkey Systems such as Pastel, Sun, Tally, etc., while 25\% used software modifications from the office such as Microsoft Excel.

Similarly, Breen et al. (2003) used 122 SMEs that have implemented Computerized Accounting Systems (CAS) and 99 SMEs that have not implemented CAS yet in Australia and found that $96 \%$ of SMEs use MYOB, Quickbooks, and Cash Flow Manager, while the remaining 
4\% use a simple self-made software. Pulakanam and Suraweera (2010) examined various obstacles faced by SMEs in India in implementing CAS and the results conclude that the complexity of software and the lack of support from software providers are a major obstacle for SMEs in operating the software. Grande at al. (2011) conducted a study in Spain regarding the effect of AIS application on performance and the results found that there was no significant relationship between the productivity of SMEs and CBAS use.

Ogundana et al. (2017) examined the relationship between information and communication technology (ICT) and accounting systems in SMEs in Nigeria and the results found a significant relationship between ICT knowledge and the accounting system. Moreover, there is also a significant relationship between ICT adoption through various accounting software packages and the accounting system.

Ezeagba (2017) examined the constraints faced by SMEs in Nigeria in adopting CBAS particularly in implementing an effective financial accounting reporting. He found that various obstacles faced by SMEs include bookkeeping that was not feasible, limited human resources, and many who had not implemented their financial transactions through the banking system. Uddin et al. (2017) evaluate the practice of applying accounting information systems to SMEs in Nangpur district, Bangladesh. The results found that only $20 \%$ of SMEs had implemented an adequate accounting system while $80 \%$ were not yet feasible.

\section{RESEARCH METHOD}

This study uses a qualitative approach to identify the needs of the most appropriate information system for VUC management in Banyumas Region by considering the conditions of each VUC (i.e., needs assessment). Data is obtained through in-depth interviews, observations, and focus group discussions. While data analysis uses the interaction method which is a long process that includes data collection, analysis, reduction, and conclusion (Miles and Huberman, 1994). The VUCs selected as sample are VUC Tri Murti in Kembaran District, VUC Tani Maju in East Purwokerto Distrcit, Mustika VUC in Sumbang District, VUC Patikraja located in Patikraja District, VUC Bahtera in Baturaden District, and VUC Endah located in Kedung Banteng District.

\section{RESULT AND DISCUSSION}

After carrying out a long process to identify the needs of the system (needs assessment) that is most suitable for VUC financial management, this study develops an accounting system that can be used by VUC in Banyumas region in running its business. This system consists of both manual and computer-based systems. For the manual system, this study compiled a system manual including discussion on general information, summary of accounting policies, account guidelines and financial report format, explanation of account codes, reporting procedures and book closure, and forms. Moreover, this study also develops the appropriate accounting software and manual instructions for using the computer-based information system. The manual system for VUC management in Banyumas Region is explained in several parts as follows.

\section{Part 1. General Information}

The discussion of general information will include:

\section{(a) Description}

In this section, the discussion will include an overview of the VUC, the scope of business activities that explain the business units run by VUC, and business assets that explain the various assets owned by VUC. 
(b) Organizational Structure

It explains the organizational structure in managing a VUC which generally includes the annual meeting of members or rapat anggota tahunan (RAT), supervisors, administrators, and business unit managers.

(c) Description, Task, and Role of Members in the Organizational Structure

This section explains the roles and functions of each part of the organizational structure, namely:

Annual Meeting of Members or Rapat Anggota Tahunan (RAT)

RAT is the highest authority in cooperative organization held every year. Decisions at member meetings are taken based on deliberation to reach consensus.

\section{Supervisors}

Each member has the right to choose and be elected as a member of the supervisor where the supervisory members are not allowed tp double their position as a board. The supervisor's term of office is determined, usually every three years, the supervisor is responsible to the RAT and has the following duties:

a. Implement the governance of VUC which includes:

- Organizational

- Implementing the policies of the organization

- Make a written report about the examination and report it to the board's members.

b. Drawing conclusion on cooperative's condition.

c. Responsible for inspection to the meeting of members.

\section{Administrators}

Administrators or management are representatives of cooperative members who are elected through the meeting of members. The management is responsible for all activities of managing the cooperative and its business. While the duties of the management are managing the cooperative and its business, holding member meetings, submitting draft work plans and cooperative income and expenditure budgets, submitting financial reports and accountability for the execution of tasks, etc. Generally, the VUC's administrators consist of head administrators, secretary, and treasurer.

\section{Unit Managers}

The composition of the unit managers in the VUC varies depending on the VUC-owned business units concerned such as the savings and loan unit manager, the manager of the agricultural production facilities unit, the departmental unit manager, the rural transport unit manager, and so on.

\section{(d) Organizational Activities}

The organizational activities of a VUC cover several cycles such as operating, revenue, and financing.

\section{Operating Cycle}

The operating cycle describes how each VUC organ works so that this cycle provides an overview of the tasks of each organ of the organization in the process of improving member welfare. The things described in this cycle, for example, include:

\section{Head of VUC or Chairman}

The Chairman is the party responsible for the sustainability of the improvement process and the welfare of members.

\section{Head of Administrator}

The duties of the head of administration relating to the operational activities cycle of the cooperative are as follows: 
1) Ensuring that all general administration activities (administrators, members, and nonmembers) are going well.

2) Ensure inventory items both purchase, procurement, maintenance and utilization according to needs.

\section{Head of Financial Affair}

The head of finance in relation to the operational activities of cooperatives is as a part that oversees and controls the linkages between things that are budgeted and their realization.

\section{Business Unit Managers}

The tasks of the business unit managers related to the operational activities cycle of the cooperative are: (1) assisting the head of finance in making a budget planning, (2) ensuring the accounting process runs smoothly, (3) providing services related to complaints, suggestions or criticism related to cooperative finance, and (4) assisting in making the unit's financial report.

\section{Staff of Finance}

The tasks of the financial staff of the cooperative business unit in the operational activities include: planning the financial needs of the business unit in coordination with the unit manager for the next accounting period, assist and work with the unit manager to coordinate and prepare financial statements in the cooperative business unit.

\section{Revenue Cycle}

Revenue is obtained in each business unit (decentralized), but at the end of the accounting period each business unit will report financial statements which are consolidated with the VUC central finance and each business unit can submit a budget for the next period. Based on the information above, the following job descriptions show each function in the VUC in handling the business revenue.

\section{Head of VUC}

The head of VUC has a responsibility to socialize, organize, and oversee the budget plan that has been ratified by the RAT to all administrators in realizing the revenue to improve the economy and welfare of members.

\section{Head of Administrators}

The Head of Administration must prepare a budget plan that is carried out during one accounting period to obtain income.

\section{Finance Manager}

The finance manager is the party responsible for all major income and other income obtained by the cooperative.

\section{Unit Managers}

The unit managers are tasked with reporting on budgetary needs to the finance manager.

\section{Staff of Finance}

The business unit's financial staff is tasked with collecting and organizing proof of transaction payments in its unit, then will record it in a general journal based on the evidence of the transaction and help the head of the business unit make a revenue statement of the business unit to compile the cooperative budget for the next period.

\section{Financing Cycle}

Payment or recognition of costs incurred in this cooperative is divided into two, namely payment of routine costs and non-routine costs. On the payment of routine costs that occur for 
business operations, the cash disbursement authority is handed over to the finance department of each cooperative business unit. However, for non-routine costs, the cash disbursement authority is held by the chairman of the board where the financial part of the business unit must make a letter of application and request the signature of the chairman of the board for the payment of the activity where usually this financing activity has a large nominal value. The following procedures for cash disbursement for non-routine costs.

\section{Finance Manager}

The finance manager receives a request for cash disbursement from the business unit, then prepares the form for submitting cash disbursement for non-routine transactions and then passes the form to the chairman for approval.

\section{Unit Manager}

The unit manager has a responsibility to record documents that have been authorized by the finance manager and have received a receipt from the applicant in the journal.

\section{Part 2. The Summary of Accounting Policies}

The preparation of the VUC Financial Report is guided by the Financial Accounting Standards for Entities without Public Accountability (SAK-ETAP). An overview of this accounting policy contains important things in the treatment of accounts in recording, classifying, summarizing transactions that occur. Matters that have not been regulated in the financial accounting system, this is because there are transactions that are not anticipated and the treatment is left to the Internal Auditor of the village unit cooperatives, as long as it does not deviate from the Statement of Financial Accounting Standards (PSAK) that are valid and based on common sense considerations. The report that will be produced by the Accounting System consists of balance sheet, calculation of business results, reports on changes in equity, cash flow statement (indirect method), notes to the financial statements, and additional information in the form of details of all items in the balance sheet and profit and loss and other information that are considered important and needed by users of financial statements.

This Financial Accounting System is intended for the preparation of monthly financial statements which at the end of the year will be integrated into annual financial statements. Other accounts that have not been listed in this Financial Accounting System Guidelines and have non-material balances to be combined in accordance with existing estimates which have similar properties. Moreover, the accounts that have not been listed in the Financial Accounting System Guidelines if necessary can be added to the chart of accounts. Deviations from the Financial Accounting System Guidelines are only permitted for certain reasons and must be approved by the Chair. In the framework of the accounting system implementation, the chairman of the VUC established the following policies:

\section{(a) Recording Process}

The recording process carried out in processing the VUC financial transaction data is done by developing Electronic Data Processing (EDP) into several stages. In the implementation phase, this financial accounting system uses the GL (General Ledger) application. Transactions that occur in this company will be separated into 5 types of transactions and for each transaction made by the accounting section will be accompanied by a journal voucher that has been numbered. Thus, it is expected that this policy can help the process of storing transaction evidence as well as the process of tracking 
documents/proof of transactions when needed. Here are 5 categories of transactions that are applied along with the journal voucher names that accompany them: (1) Cash Entry Transaction> Cash Proof, (2) Cash Out Transaction> Cash Proof, (3) Incoming Bank Transactions> Bank Proof, (4) Outgoing Bank Transactions> Bank Proof, and (5) Non Cash \& Non Bank Transactions> Memorial Evidence

The next stage is expected that the Financial Report can be automatically compiled as EDP output.

(b) Revenue and expense recognition

Recognition of all revenues and expenses related to the operation of business activities is recognized based on accrual basis.

1. Operating Income

Revenue is recognized when there is a sale transaction of merchandise without changing the form of merchandise.

2. Other Income

Other income is income derived other than the company's main activity such as interest income on savings. This income is recognized when there is an official supporting document that contains the nominal and basis of the cause of the transaction.

3. Cost of Goods Sold

Cost of goods sold is recognized in accordance with the value of costs spent on obtaining merchandise.

4. Operating Expenses

All operating expenses are recognized in accordance with the time and proportion of the charges (accruals), such as central operating expenses, fertilizer unit costs, electricity unit expenses, savings and loan unit expenses, freight unit expenses, etc.
5. Extra Ordinary Expenses

All expenses outside the business are recognized in accordance with the time and proportion of the expenses (accrual).

(c) Adjustment Journal

The Adjustment Journal will be created at the end of the business period with memorial evidence as the basis.

(d) Cash Management

Management and responsibility for cash related to all business transactions of the company are centered on the financial part.

(e) Depreciation

All tangible fixed assets will be depreciated using the straight-line method with a residual value of a certain percentage of the acquisition value.

\section{Part 3. Account Guidelines and Financial Report Formats}

(a) Basic Ledger Account Classification

1) In accordance with the standard of transaction account classification, the VUC "Bahtera" Baturaden (as a sample) is classified into 5 groups and each group consists of several sub-groups. The assets consist of current and non-current assets

2) The liabilities consist of current and long-term liabilities

3) The equity is divided into 4 groups, i.e., principal deposits, mandatory deposits, reserve, and current year SHU

4) Income is divided into operating and non-operating income

5) Costs or expenses consist of cost of goods sold, operating expenses, and extraordinary expenses. 


\section{(b) Format and the presentation of financial statements}

Following the applicable accounting standards for cooperative, the financial statements consist of balance sheet, report on the calculation of business result, Reports on Changes in Equity, cash flow statement (indirect method), and notes of financial statement.

\section{(c) The Basis in The Classification of Budget Account}

Based on the cooperative statutes, the classification of the VUC Bahtera Baturaden budget account is classified into 2 groups, i.e., revenue and expenses. Sources of revenue come from several business units such as fertilizer, electricity, saving and loan, etc. Meanwhile, expenses consist of several items such as administrative and operating expenses.

(d) The Pattern of Budget Formulation

The budget is based on the activity pattern in each of business unit, where the revenue is decentralized for each business unit and expenses are allocated based on the needs of each business unit.

(e) The Procedures for Giving Account Codes in the Revenue and Expenses Budget Plan

Account codes on budget transaction accounts are carried out by assigning numbers to each group, class, and type of account with the following provisions:

1. The account group is numbered 4 to 5

a) The Income Group is coded 4

b) The load group is coded 5

2 . The account group is numbered 1 to 10

The number of class accounts for each business unit is different depending on the needs.
3. Account types are numbered 1 to 10 The number of types of accounts for each business unit is different depending on needs.

(f) Details of The Account Codes

Account codes for daily transactions must be detailed and combined between assets, liabilities, equity, income, and expenses.

\section{Part 4. The Explanation of Codes of Account}

\section{(a) Balance Sheet Accounts}

The accounts listed on the balance sheet are only accounts that reflect the financial position of a business entity on a specific date which consists of:

\section{Assets}

Assets are economic benefits of the future that are reasonably certain and obtained or controlled by an entity as a result of transactions from the past events (IASB, 2009) which consist of current and non-current assets. Current assets include cash/bank and wealth or other sources that can be expected to be cashed into cash/bank, sold or used up in one year of company activities. The current assets of VUC generally consist of cash and bank with account code 1100, shortterm deposit with account code 1200 , receivables with account code 1300 , etc. Moreover, including non-current assets are a long-term investment that could be coded by 1700 and fix assets with account code 1800 .

\section{Liabilities}

Liability is defined as the sacrifice of future economic benefits that is quite certain arising from the necessity of a business entity to transfer assets or provide/deliver services to other entities as a result of past transactions (IASB, 2009) which consists of shortterm and long-term liabilities/obligations. Short-term liabilities are cooperative debt used for working capital needs and maintaining 
cooperative liquidity and must be repaid in the period which is more than one year. For example are funds remaining from business results (SHU funds) that could be given the account code of 2100. SHU funds are the remaining business proceeds after deducting the reserve fund, distributed to members in proportion to the business services carried out by each member with the cooperative, and used for cooperative education and other requirements of the cooperative, in accordance with the decisions of the member meeting. Other examples of short-term liabilities for VUC are audit fund debt with the code of account 2200 , credit risk fund with the code of account 2300, members' deposit with the code of account 2300, etc. Meanwhile, long-term liabilities are a type of obligation with payment period is more than one year such as bank loan, and other types of liabilities.

\section{Equity}

Equity is a residual right on a company's assets after deducting all liabilities (IAI, 2011). In another word, equity is defined as residual rights to indicate that equity is not an obligation. It means that equity is not a sacrifice of future economic resources because it is defined on the basis of assets and liabilities, the value of equity also depends on how assets and liabilities are measured. In term of cooperative, the equity generally consists of principle deposit (account code 3100), mandatory deposit (account code 3200), reserve (account code 3300), and current year of the remaining business result (i.e, SHU with account code 3400).

Principal deposit is the same amount of money which must be paid by members to the cooperative when joining into membership and it cannot be withdrawn as long as the person is still a member.
Mandatory deposit is a number of deposits that should not be the same amount among members which must be paid by a member during his/her participation in the cooperative. Similar with principal deposit, the mandatory deposit also cannot be withdrawn as long as the person is still a cooperative member.

According to the Regulation of the Minister of Cooperatives and Small and Medium Enterprises No. 4 of 2012 concerning General Guidelines on accounting for Cooperative, Reserve funds are obtained and collected from the allowance for a portion of the remaining business results (SHU) each year with the intention that if at any time it is necessary to cover losses and the need to cultivate capital. The position of the reserve fund in the liabilities side indicates that if a loss occurs, it will automatically be compensated with the reserve fund and if there is not enough added to the storage. It is understandable that there are provisions in the commercial law that if a company's loss reaches more than half its capital must be announced. Because the company's capital has decreased and is at risk.

Similarly, according to the Regulation of the Minister of State for Cooperatives and Small and Medium Enterprises No. 4 of 2012, the current year of remaining business result (SHU) is: (1) Remaining Business Results is the sale of goods/services as cooperative income obtained in one accounting period minus the operating costs, depreciation and other costs, including taxes in one period the accounting concerned; 2) The remaining business proceeds after being deducted by reserves are distributed to members and part of it is used for the purposes of implementing cooperative education; 
$3)$. In addition to meeting the needs of reserves, members and education funds, cooperatives can divide the remaining business proceeds for other purposes, according to the decision of the member meeting or the provisions of the articles of association, or the provisions that apply to

\section{(b) Income Statement Accounts}

\section{Revenue/Income}

Revenue is the gross cash flow from economic benefits arising from the entity's normal activities during a period if the inflows result in an increase of capital that does not originate from investment contributions (IAI, 2011). VUC operating income is income derived from each cooperative business unit such as fertilizer unit with fertilizer and drug sales transactions, electricity unit with electricity payment services, saving and loan unit with credit loans, transportation unit with public transportation services, and rice milling unit (RMU). Meanwhile, extraordinary income is an income that is not directly related to business activities such as interest income.

\section{Expenses}

Expenses consist of operating expenses such as salary for employees, utility expense, etc.

\section{Part 5. Report and Book Closing Procedures}

The report and book closing procedures for cooperative could be described as follows:

a) Initial Balance Sheet. The real account balance of the previous month's report will be the initial balance sheet in the following month.

b) Preparation of transactions for the following month.

c) Check the addition or change of account code.

d) Prepare a pivot template. e) Enter data related to the initial balance sheet in the general journal sheet.

f) Enter the transaction proof accompanied by a voucher journal that occurred at VUC to a general journal.

g) Entry of transactions for each unit to a general journal.

h) Run the Pivot Table function to create a ledger.

i) Run the Pivot Table function to create a trial balance.

j) Run the Pivot Table function to create balance sheet work paper.

k) Run the Pivot Table function to create a working paper to report the calculation of the remaining business results.

1) Make a balance sheet report from the balance sheet worksheet.

m) Make a report on the calculation of the remaining business results and report on changes in equity from the working paper report on the calculation of the remaining business results.

n) Make cash flow statements both direct and indirect methods derived from the balance sheet, balance sheet and report on the calculation of the remaining operating results.

o) Make sure the report is appropriate.

p) Repeat the process the following month.

\section{Part 6. Forms}

The forms used in VUC are the Journal Voucher System. This voucher journal system will be a cover for transaction proof for every transaction that occurs in the VUC. The concept of a voucher journal is to ensure that every single transaction recorded in the Journal is recorded as the source of the recording. Therefore, the recording evidence will be arranged as follows:

a) Proof of transaction will be covered by a journal voucher.

b) Proof of transaction will be recorded in a voucher journal.

c) The voucher journal will be used as a basis for entry into general journals. 
d) Transactions that have been entered into general journals will be processed into ledgers, trial balance and financial statements.

e) The resulting financial statements include balance sheet, report on the calculation of operating results, statements of changes in equity, and cash flow statements for both direct and indirect methods.

The following is an example of a voucher journal that could be used for VUC along with its description:

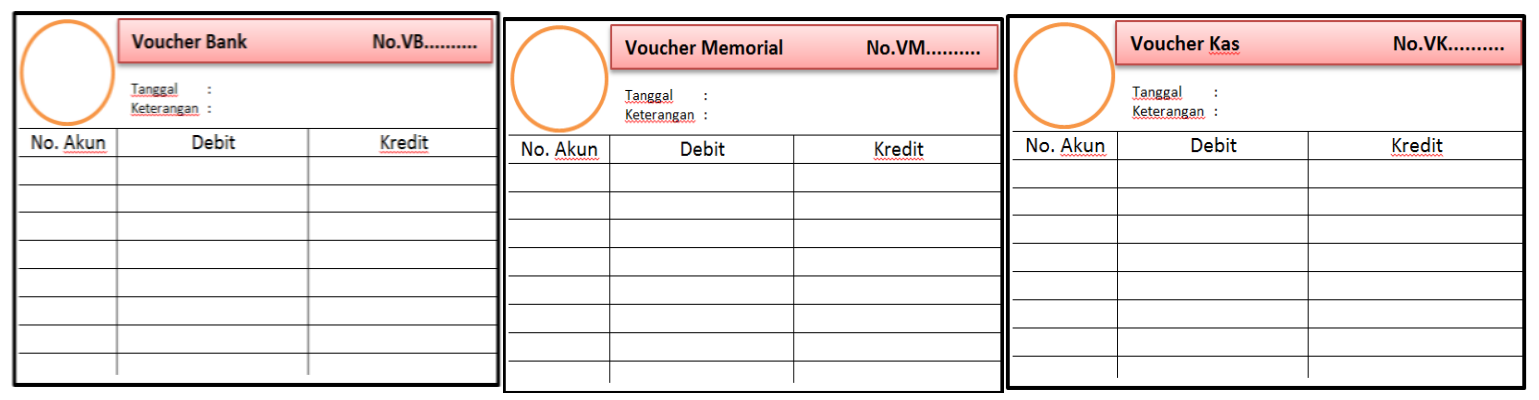

Figure 1. Example of a Voucher Journal

Where:

Circle: VUC Stamp

Date: Shows the date of the transaction. JVK/JVB/JVM No.: Indicates the journal number that will be entered into the system where there cannot be the same JV number, for example, JV-VUC-08-01

Description: Explanation of the transaction

No. Account: Filled with transaction account code.

Debit: Filled with the nominal amount of the debit account.

Credit: Filled with the nominal credit account.

After completing the manual accounting system as explained above, this study develops computer-based accounting system for managing the financial activities of VUC in Banyumas by using general ledger application with pivot table from the Microsoft Excel.

\section{CONCLUSION}

This study investigates the needs of accounting system for VUC in Banyumas region by implementing a qualitative approach where data were collected through observation, in-depth interview, and focus group discussion. Then, data were analyzed with interactive method following several steps such as collection, reduction, presentation, and drawing conclusion. Moreover, based on collected data this study develops both manual and computerized accounting system for VUC in Banyumas Region. It is expected that by using both systems the VUCs in Banyumas region will be more developed in managing their business so that they are able to serve the daily needs of the members. In another word, with the rapid development of VUC in its business will benefit the people surrounding the area of VUC by improving their welfare.

\section{REFERENCES}

Breen, J., Sciulli, N., and Calvert. (2003). The Use of Computerized Accounting Systems in Small Business. Proceeding of $16^{\text {th }}$ Annual Conference of Small Enterprise Association of Australia and New Zealand, 1-12.

Bodnar, G., and Hopwood, W. (2010). Accounting Information System, $12^{\text {th }}$ Edition, Prentical Hall, New Jersey. 
Ezeagba, C. (2017). Financial Reporting in Small and Medium Enterprises (SMEs) in Nigeria, Challenges and Options. International Journal of Academic Research in Accounting, Finance and Management Sciences, 7 (1), 1-10.

Grande, E., Estebanez, R., and Colomina, C. The Impact of Accounting Information Systems (AIS) on Performance Measures: Empirical Evidence in Spanish SMEs. International Journal of Digital Accounting Research, 11, 25-43.

IASB, 2009. Training Materials for The IFRS for SMEs, London. Retrived from www.iasb.org

IAI, 2011. Standar Akuntansi Keuangan untuk Entitas Tanpa Akuntabilitas Publik. Salemba Empat, Jakarta.

Instruction of Indonesian President No. 4. (1984). Concerning The Development of Village Unit Cooperative as Service Center for Its Members.

Miles, M.B., and Huberman, A.M. (1994). Qualitative Data Analysis: An Expanded Sourcebook. Thousand Oaks. Calif, Sage.

Ogundana, O., Okere, W., Ayomoto, O., Adesanmi., D., Ibudunni, S., and Ogunleye, O. (2017). ICT and Accounting System of SMEs in Nigeria. Management Science Letters, 7, 1-8.

Pulakaman, V., and Suraweera, T. (2010). Implementing Accounting Software in Small Business in New Zealand: An Exploratory Investigation. Accountancy Business and The Public Interest, 9, 98-124.

Regulation of the Minister of Cooperatives and Small and Medium Enterprises No. 4 year 2012 concerning General Guidelines on accounting for Cooperative,

Relhan, A. (2013). E-Accounting Practices of SMEs in India. International Journal of Technical Research, 2 (1), 1-10.
Riswan, R., Suyono, E., and Mafudi, M. (2017). Revitalization Model for Village Unit Cooperative in Indonesia. European Research Studies Journal, Vol. 20 No. 4A, 102-123.

Ropke, J. (1995). The Economic Theory of Cooperative Enterprises in Developing Countries, with Special Reference of Indonesia. Marburg: University of Marburg.

Sam, M., Hoshino, Y., and Tashir, M. (2012). The Adoption of Computerized Accounting System in Small Medium Enterprises in Melaka, Malaysia. International Journal of Business and Management, 7 (18), 12-25.

Suyono, E., Farooque, O.A., and Riswan, R. (2016a), Toward a Model of Traditional Retailers and Sellers Empowerment in Improving Competitiveness Against Modern Markets in Banyumas Region, Indonesia. DLSU Business and Economics Review, 25 (2), 147-165.

Suyono, E., Rokhayati, H., and Hasanah, U. (2016b). Pengelolaan Baitul Mal wa Tamwil di Kabupaten Banyumas, Jawa Tengah. Jurnal Visioner \& Strategis, 5 (1), 23-33.

The 1945 Constitution. 1945. Concerning Foundations of Republic of Indonesia.

Tijani, O.M., and Mohammed, A.K. (2013). Computer-Based Accounting Systems in Small and Medium Enterprises: Empirical Evidence from a Randomized Trial in Nigeria. Universal Journal of Management, 1(1), 13-21.

Uddin, R., Biswas, T., Ali, J., and Khatun, M.S. (2017). Accounting Practices of Small and Medium Enterprises in Rangpur, Bangladesh. Journal of Business and Financial Affairs, 6 (4), 1-7. 